\title{
Triassic - Jurassic Geology of the Northern Part of the Culpeper Basin, Virginia and Maryland
}

by K. Y. Lee

U.S. Geological Survey

Open-file report $79-1557$ 


$$
\begin{aligned}
& \text { Triassic-Jurassic Geology of the Northern Part } \\
& \text { of the Culpeper Basin, Virginia and Maryland: } \\
& \text { by K. Y. Lee } \\
& \text { Introduction }
\end{aligned}
$$

The Culpeper Basin is one of several faulted Meso/zoic troughs bordering the east front of the Appalachian Mountains in eastern North America. Triassic and Jurassic siltstone, sandstone, and conglomerate and Jurassic basalt and diabase underlie the basin. The sedimentary rocks in the basin constitute a distinctive sequence of continental "red beds", consisting largely of clastic fluvial and lacustrine deposits. Along the east side of the basin the strata generally dip gently westward, but the dip becomes progressively steeper to the west-northwest in proximity to the major border fault fronting the Blue Ridge, The sedimentary rocks and interbedded basalt flows are cut and locally metamorphosed by intrusive tholeitic diabase sills, dikes and stocks. The geologic maps of the northern part of the basin, presented here, cover about $1060 \mathrm{~km}^{2}$, of which $82 \%$ is in Virginia and the remainder is in Maryland (Fig. 1).

Figure I near here.

Roberts (1922, 1923, 1928) subdivided the red bed sequence of sedimentary rocks in virginia which he thought to be entirely of Triassic age, into the Manassas Sandstone below and Bull Run Shale above. Jonas (1928) adopted the name New Oxford Formation for the

$$
\begin{aligned}
& -1- \\
& \text { p. Ia follows }
\end{aligned}
$$


Names of quadrangles in this report:

Frederick

Point of Rocks

Buckeys town

Waterford:

Poolesville

Germantown

Lincoln

Leesburg

Sterling

Seneca

Middleburg

Vienna

Gainesville

Manassas

Fairfax

Nokesville

Arcola (Lee, 1978)

Herndon (Eggleton, 1975)

$77^{\circ} 16^{\circ}$ 
lowest stratigraphic unit of the Upper Triassic Newark Group rocks in Maryland. Cornet (1977) proved the presence of Jurassic rocks in the Virginia portion of the Culpeper Basin and established the TriassicJurassic boundary, based on a detailed palynostratigraphic study.

The present geologic study of the Culpeper Basin was carried out from the fall of 1973 to 1977 . The 16 partial geologic map quadrangles of the northern part of the basin present part of the results of this study. An earlier report (Lee, 1977) presented a preliminary summary of the revised stratigraphy. This open-file report utilizes a stratigraphic nomenclature which does not yet have formal standing, The Culpeper Group is herein used for the distinctive interfingering sequence of Upper Triassic and Lower Jurassic sedimentary and basaltic rocks within the basin. It is subdivided, in ascending order, into the Manassas Formation, the Balls Bluff Siltstone, and the Bull Run Formation. The Upper Triassic Manassas Formation contains the Reston Member and the Tuscarora Creek Member at the base, overlain by the Poolesville Member. The middle unit, the Balls Bluff Siltstone, conformably overlies the Poolesville Member and is laterally gradational and intertongues with the Lower Jurassic Bull Run Formation. The Bull Run Formation is subdivided into the Leesburg Member at the base, overlain by the Catharpin Creek Member, which contains the Mt. Zion Church basalt, the Hickory Grove basalt, and the Sander basalt. The Catharpin Creek Member is overlain conformably by the Mountain Run Member. The rocks of the Culpeper Group are generally mantled by unconsolidated Upper Teritary(?) and Quaternary terrace deposits and mountain wash colluvial deposits, and Recent alluvial deposits. 
Economic Geology

The northern part of the Culpeper Basin contains extensive deposits of rock materials suitable for crushed stone, aggregate, rock metal, and rip-rap, as well as deposits formerly used for dimension stone, flagstone, and building stone. Raw materials suitable for the manufacture of brick, tile, and agricultural lime are also abundant. Supplies of ground-water adequate for domestic purposes are available in most areas, and potentially large supplies sufficient for commerical uses are likely in some areas (A. J. Froelich 1979, pers. commun.). Metallic and non-metallic mineral deposits have been extensively prospected in the past, but only locally mined on a small scale.

Diabase and basalt are extensively quarried for crushed stone, aggregate, road metal, fill, subbase, and rip-rap. The materials commonly meet State Highway specifications because of their uniform texture and toughness; they are readily quarried because of an intersecting network of closely to moderately spaced joints that facilitate splitting and removal of the otherwise massive rock.

Hornfels and granulite of the thermally metamorphosed zone have locally been quarried and crushed for subbase and road metal. Limestone conglomerate in Loudoun County and marble at Leesburg were formerly quarried for local use as crushed stone and as a source of agricultural lime.

Resistant sandstone of the Poolesville Member had been quarried for dimension stone along the Potomac River in Loudoun County, Va. 
and Montgomery County, Md. Siltstone and sandstone of the Catharpin Creek Member were quarried for flagstone in Loudoun County, Va. Limestone conglomerate ("Potomac Marble") was quarried from outcrops of the Leesburg Member at Leesburg for use as decorative columns in Statuary Hall of the U.S. Capitol. The Balls Bluff Siltstone has properties suitable for common brick and tile manufacture.

The metallic copper and iron mineral deposits in the basin were prospected and locally mined during the past. These deposits generally occur in granulite and hornfels of the inner zone of contact aureoles, within fracture in diabase, and as fissure-fillings in sandstone and siltstone away from contact aureoles. Principal minerals are chalcopyrite, magnetite, specularite, bornite, and malachite. Copper-bearing greenish-gray siltstone and silty shale in the basin were probably formed during the diagenesis of sediment.

The non-metallic deposits of barite were formerly mined in Fauquier County, Va. They occur as fissure-fillings in siltstone and shale near diabase intrusives (see Watson, 1907, Edmundson, 1938).

On the basis of detailed study of environmental problems in Fairfax County, Va., A. J. Froelich (1979, personal commun.) considers that the most serious potential environmental problems in the area are related to waste disposal and possible contamination of ground water resources by septic tank effluent or landfill leachate. Other common problems relate to foundation instability caused by high shrink-swell soils on diabase or on fault gouge due to the presence of montmorillonite and by unconsolidated Mountain Wash colluvial deposits or in local areas underlain by friable gravels of the 
Reston Member. Sinkholes and subsurface caverns are sporadically and unpredictably present in the widespread limestone conglomerate terrain underlain by the Leesburg Member. The presence of these karst features, especially where capped and concealed by Mountain Wash deposits, are a serious potential hazard to construction or buildings in this area. 


\section{REFERENCES CITED}

Cornet, Bruce, 1977, The palynostratigraphy and age of the Newark Supergroup: University Park, Pa:, The Pennsylvania State University, unpublished Ph.D. dissertation, 505 p.

Edmundson, R. S, 1938, Barite deposits of Virginia: Virginia Geological Survey Bulletin 53, 85 p.

Lee, K, Y., 1977, Triassic stratigraphy in the northern part of the Culpeper basin, Virginia and Maryland: U,S, Geological Survey Bulletin 1422-C, 17 p.

Lee, K. Y., 1978, Geologic map of the Arcola quadrangle, Virginia:

U.S. Geological Survey Map MF-973, scale 1:24,000.

Eggleton, R. E., 1975, Preliminary geologic map of the Herndon quadrangle, Virginia: U.S. Geological Survey open-file report $75-386$, scale 1:24,000.

Roberts, J, K., 1922, The Triassic of northern Virginia; Baltimore, Maryland, Johns Hopkins University, unpublished Ph.D. dissertar tion, 272 p.

Roberts, J. K:, 1923, Triassic basins of northern Virginia: Pan-Am Geologist, v: 29, n, 3, p: 185-200.

Roberts, J: K, 1928, The geology of the Virginia Triassic: Virginia Geological Survey Bulletin 29, 20.5 p.

Watșon, T: L:, 1907, Geology of the Virginia barite deposits; American Institute of Mineral Engineering Transactions, v. 38, p. $712-713$ 


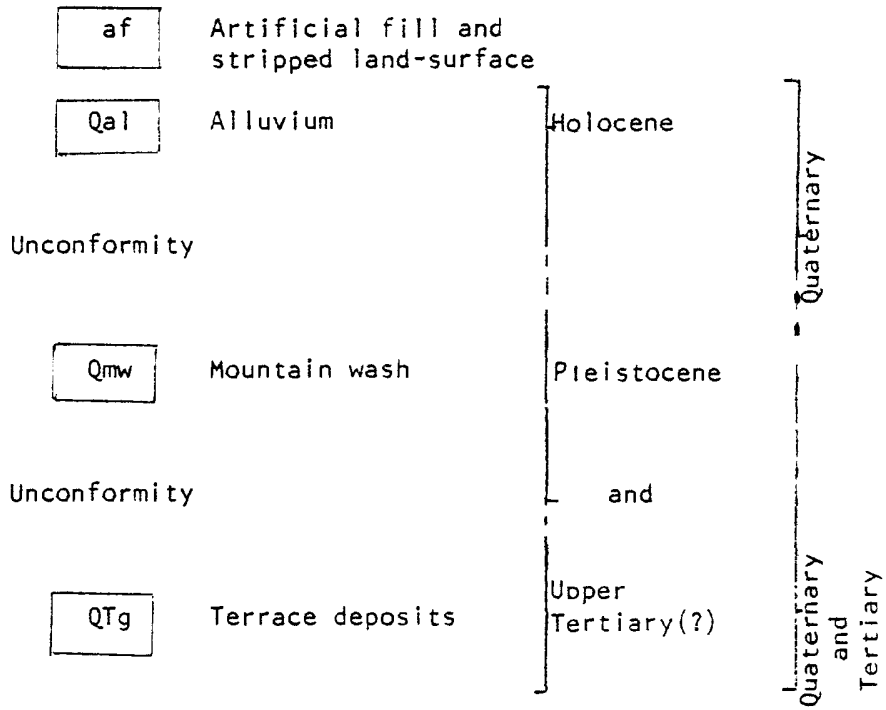

UNCONFORMITY

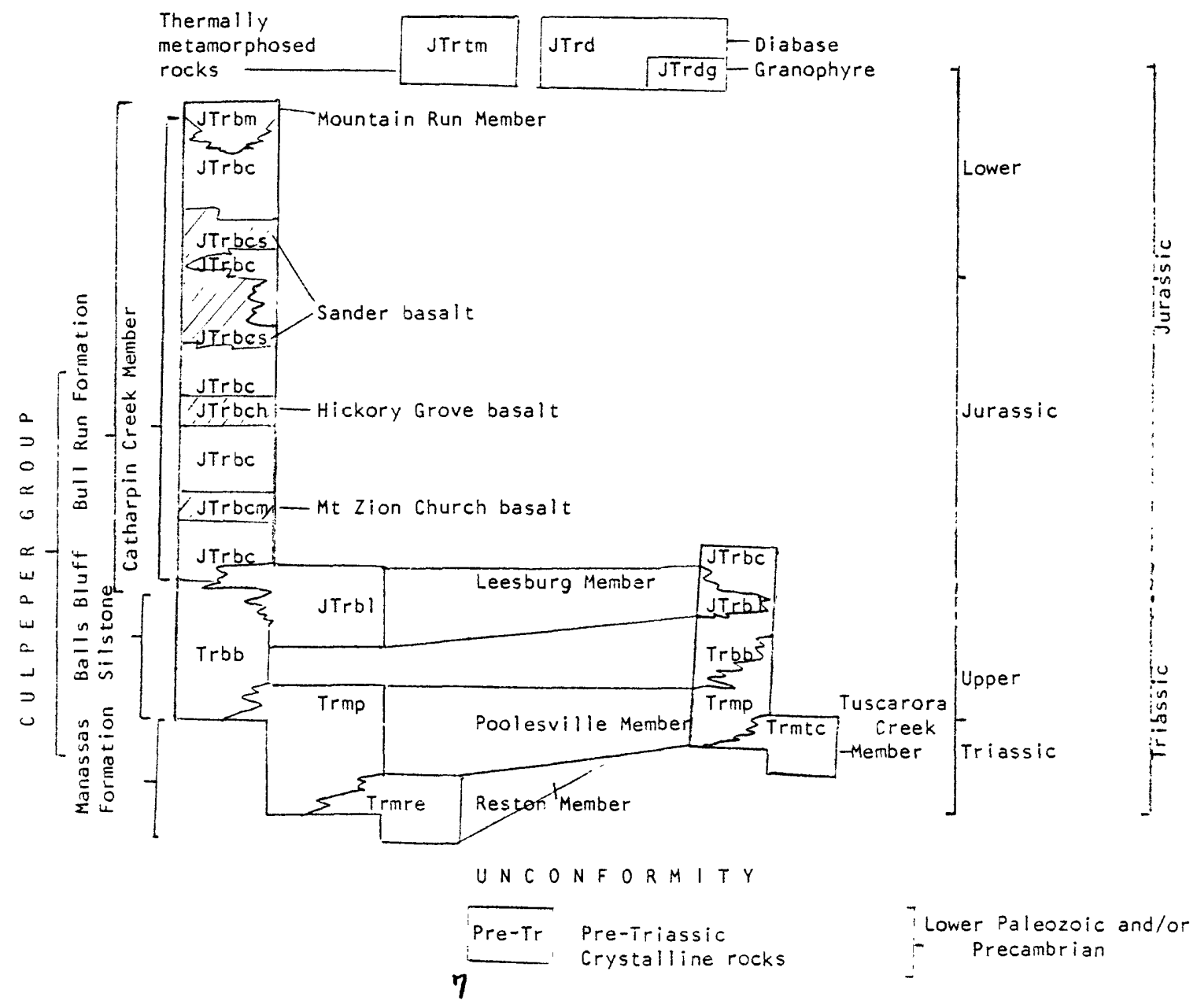


Artificial fill and stripped land-surface. Manmade features in construction areas.

\section{Unconsolidated Sediments}

Qal Alluvium - silt, sand, clay, and gravel; generally moderately well-sorted and interlayered. Commonly, sand layers contain gravel consisting of lenses, rounded to subrounded rock fragments. Estimated to be 0.5 to more than $15 \mathrm{~m}$ thick.

Mountain Wash - Gravel, silt, and sand. Chiefly gray and moderate-reddish-brown to pale-yellowish-orange, rounded to angular quartzite and vein quartz fragments, and light-gray and grayish-red quartz and feldspar sand in a silt matrix. Estimated to be 0.3 to about $30 \mathrm{~m}$ thick. 
Terrace Deposits - Sand, gravel, and clay. Gray, grayish-orange, grayish-red, and moderate-reddish-brown, rounded to subrounded quartzite fragments, and quartz and feldspar sand in a clayey silt matrix. Locally yellowish-brown clay is dominant. Estimated to be 1 to about $35 \mathrm{~m}$ thick. 
Gray to dark-gray, medium-bluish-gray, and olive-black hornfels, granulite, and quartzite, chiefly metamorphosed feldspathic, micaceous, argillaceous, arenaceous, ferruginous, and clacareous sandstone, siltstone, and minor shale; light-gray and gray marble, metamorphosed limestone conglomerate and slightly thermally altered basalt.

Hornfels is the dominant type of the metamorphosed argillaceous rocks. In the contact aureoles, an inner zone is generally characterized locally by biotite, cordierite, quartz, and plagioclase; succeeded by a middle zone of cordierite, andalusite, plagioclase and quartz; and followed by an outer zone of chlorite, epidote, and quartz. Granulite and quartzite form fused lenses, bands, and irregular masses. The inner zone is characterized either by a zone of decussate biotite, plagioclase, and fused quartz, or by a zone of hornblende, plagioclase, titanite, and myrmekite-quartz; succeeded outward either by a zone of cordierite, andálusite, plagioclase, and fused quartz, or by a zone of abundant black tourmaline, plagioclase, and quartz; and generally followed by an outer zone of chlorite, epidote, and at places, spotted aggregates of recrystallized feldspar. Marble consists of calcite, lime-garnet, diopside, and serpentine, associated with minor amounts of vesuvianite, magnetite, and wollastonite. 
JTrd JTrdg near margins aphanitic, and locally to very coarse-grained; consists chiefly of dark-grayish-green to black discrete crystals of augite and pigeonite, light-gray laboradorite, and with scattered granules or aggregates of magnetite and ilmenite. Pegmatitic and granophyric facies occur as irregular pods and bands within the diabase. Granophyre - Pale pink to pink, medium- to coarse; consists chiefly of sodic plagioclase with a turbid appearance and abundant micropegmatitic quartz and potassium feldspar; mafic minerals include hornblende and clinopyroxene; Minor biotite,chlorite, actinfolite, magnetite, ilmenite, and apatite.

Sedimentary Rocks and Basalt of the Culpeper Group

\section{BULL RUN FORMATION}

JTrbm

\author{
Mountain Run Member-Conglomerate, dusky-yellowish, dusky-grayish-, \\ and moderate-yellowish-green, angular to subrounded clasts of \\ greenstone and subordinate amount of subrounded clasts of quart- \\ zite and vein quartz, in a clayey sand and silt matrix, firmly \\ cemented by silica. Estimated to be 160 to $350 \mathrm{~m}$ thick.
}


Catharpin Creek Member - Sandstone, siltstone, minor conglomerate, and shale. In part interlayered with basalt flows; and locally contains fossiliferous impure limestone, carbonaceous shale and siltstone, and thin coal seams in the Middleburg quadrangle, Va. and thin coal beds in the Frederick quadrangle, Md. Estimated to be 61 to about $2,170 \mathrm{~m}$ thick.

JTrbcs Sander basalt - Dark-gray to blackish- or blush-gray; mostly holocrystalline and equigranular, in part microcrystalline or glassy and porphyritic; consists of augite and plagioclase, chiefly labradorite and andesine, in part exhibiting ophitic texture. Zeolite-filled vesicles common in the upper part of this sequence. Hydrothermally altered and locally mineralized with copper sulfide $\$$ minerals. Interlayered with sandstone and siltstone of the Catharpin Creek Member. Estimated to be 136 to $546 \mathrm{~m}$ thick.

JTrbch Hickory Grove basalt - Medium-gray to medium-dark-gray, and dark-gray; very fine to very coarse; mostly equigranular and holocrystalline; euhedral or subhedral crystals of plagioclase, chiefly labradorite and andesine, occur in a groundmass of augite. Vesicles mainly in the upper part of the sequence. Estimated to be 35 to $212 \mathrm{~m}$ thick. 
JTrbem Mount Zion Church basalt - Medium-gray and dark-gray; very fine to medium; porphyritic in part; mostly equigranular and holocrystalline; augite and plagioclase, chiefly labradorite and andesine, display ophitic or subophitic texture. Vesicles occur in the upper part of the sequence. Well-developed columnar joints. Locally contains irregular lenses of grayish-red to dark-red siltstone. Estimated to be 9 to $142 \mathrm{~m}$ thick.

JTrbl Leesburg Member - Conglomerate, light- to blackish-gray darkgray. and pinkish-red clasts of limestone, dolomitic limestone, and dolomite, with scattered fragments of quartzite, vein quartz, schist, slate, and siltstone, in a matrix of carbonate rock granules, quartz and chert sand, silt, and rare greenstone, firmly cemented by calcite and minor clay. Estimated to be 36 to $1,072 \mathrm{~m}$ thick.

Trbb BALLS BLUFF SILTSTONE - Siltstone, dusky-red, dark-red, grayishred, and in part, light-greenish-gray, light-bluish-gray, greenish-gray, and medium-dark gray to dark-gray; feldspathic, micaceous, highly calcareous, ferruginous, and clayey; thin to thick bedded and massive; ripple bedded and laminated; locally contains thin lenses of gray limestone and dolomite; layers and lenses of carbonate oöids, and aggregates of carbonate concretions. Layers of sandstone and silty shale scattered throughout the sequence. Estimated to be 76 to $1,690 \mathrm{~m}$ thick. 
MANASSAS FORMATION

Poolesville Member - Sandstone, dusky-red to grayish-red and very dark-red; very fine- to medium-grained, mostly mediumgrained; micaceous, feldspathic, ferruginous, silty, clayey, and in part calcareous; consists chiefly of quartz and feldspar grains in silt matrix, cemented by clay, silica, and cllakite locally. Thick to very thickbedded or massive, and planar to cross-laminated. In the lower part of the sequence, contains lenses and layers of light-gray to gray, medium- to very coarsegrained, feldspathic sandstone, and conglomerate of quartzite fragments. Compact, dark-red silty shale clasts occur locally in the upper part of the sequence. Estimated to be 150 to $1,060 \mathrm{~m}$ thick.

Tuscarora Creek Member - Conglomerate, light- to dark-gray and pinkish-red, very fine- to very coarse-grained, angular to subangular limestone and dolomitic limestone clasts within a matrix chiefly of limestone and dolomitic limestone granules, clayey sand, and silt; cement is calcite. Estimated to be 21 to $67 \mathrm{~m}$ thick, but locally absent. 
Reston Member - Conglomerate and sandstone generally loosely coherent near the surface. Conglomerate consists of abundant to sparse angular to subangular pebbly to cobbly clasts of greenish-gray mica-schist, light-gray to gray rounded to subrounded quartzite and vein quartz, and feldspathic sandstone in a duskyred, dark-red, very dusky-red-purple, and moderate-brown quartz and feldspar sand, silt and clay paste. Sandstone, dusky-red, dark-red, and very dusky-red-purple; medium- to very coarsegrained; micaceous, ferruginous, silty, and clayey; consists chiefly of quartz and feldspar grains, in silt matrix. Very thick-bedded, massive, cross-laminated locally. Both of these rocks are generally loose to semicompact, and intermixed. Estimated to be 0.5 to $50 \mathrm{~m}$ thick, but locally absent.

\section{PRE-TRIASSIC CRYSTALLINE ROCKS}

Pre-Tr Undifferentiated pre-Triassic crystalline rock outside the Culpeper basin. 
Contact, approximately located; dotted where concealed.

Fault, approximately located; bar-and-ball on downthrown side; dotted where concealed.

Strike and dip of beds

$\theta$

Horizontal beds

Strike and dip of overturned beds

Strike and dip of principal metamorphic foliation

Strike and vertical metamorphic foliation

Minor fold-showing plunge

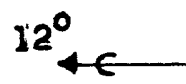

Anticline

$10^{\circ}$

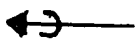

Syncline

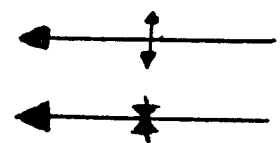

Anticline, showing crestline and plunge

Syncline, showing trough 1 ine and plunge 
Strike and dip of joints. In case of multiple joints, point of observation is at intersection of symbols

Inclined

Vertical

Direction of paleocurrent; measurement at apex based on cross lamination of sandstone and imbricate structure of rock fragments in conglomerate

Stone quarry

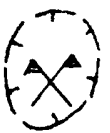

Active

Mine, prospect or quarry

Abandoned. Cu-Copper Ba-Barite

Abandoned sand and gravel pit

$\bullet$

Fossil locality

Sample localities for chemical analyses

$x^{c} x_{x}^{\infty}$

Locality of coal seams 